Sandra Zīle Gereiša, $M g$. sc., $M g$. iur.

Latvijas Universitātes Juridiskā fakultāte, Latvija

Dace Kalniņa, Latvija

\title{
MEDIATORA IZAICINĀJUMI
}

\section{CHALLENGES OF MEDIATOR}

\begin{abstract}
Summary
A successful process of mediation is inconceivable without trust. Usually, the parties in disagreement have a very tense or even detrimental relationships. Their level of mutual trust is extremely low, the tension between them is very high, and the conflict seems to be unmanageable. The conflict resolution process itself is mostly unfamiliar to the parties, they must trust the unknown. However, lack of trust toward the mediator and the mediation process leads to a failure to achieve significant results or to no results at all. However, there are effective ways to increase the confidence of the parties in a relatively short time. Neutrality of the mediator is one of the basic principles of mediation. It is included in the Law of Mediation, the Code of Conduct for Certified Mediators, and in the European Code of Conduct for Mediators. Nevertheless, the importance of neutrality in the mediation process is extensively discussed: starting from the first mediator training sessions and role plays, it is still mentioned as one of the most important challenges for practicing mediators.

Mindfulness is a fundamental quality of a mediator. In the recent years, the mindfulness phenomenon in the world and in Latvia has been quite extensively studied and applied. The importance of the concept of mindfulness is demonstrated by the fact that over the last ten years this concept is widely used by psychologists and practitioners in various fields of psychology, and many studies have confirmed the meaning and importance of mindfulness. Mediation is an interdisciplinary area that involves psychology, jurisprudence, sociology, and other fields, thus, the awareness of mediator is of a crucial importance.
\end{abstract}

Atslēgvārdi: mediators, klients, pušu uzticēšanās, mediatora neitralitāte, konfidencialitāte, apzinātība mediācijā

Keywords: mediator, client, party trust, mediator neutrality, confidentiality, mindfulness in mediation

Mediatora darbs ir aizraujošs, nozīmīgs un arī izaicinājumiem bagāts. Savstarpēji daloties darba pieredzē, mediatori min dažādas situācijas, kurās saskārušies ar izaicinājumiem. Šajā rakstā autores analizējušas biežāk pieminētos - mediācijas pušu uzticēšanās iegūšanu un mediatora neitralitāti. Kā arī mazāk aktualizēto, tomēr neapšaubāmi mūsdienīgam mediatoram nozīmīgo mediatora apzinātības jautājumu.

Veiksmīgs mediācijas process nav iedomājams bez uzticēšanās. Parasti puses, kam ir domstarpības, ir ḷoti saspringtās attiecībās, un to uzticēšanās līmenis vienai pret otru ir ārkārtīgi zems. Arī konflikta risināšanas process pusēm visbiežāk ir svešs, tām jālaujas nezināmajam. Taču ir efektīvi veidi, kā relatīvi īsā laikā vairot pušu uzticību. 
Mediatora neitralitāte ir viens no mediācijas pamatprincipiem. Tā ir ietverta mediācijas likumā, Sertificētu mediatoru ètikas kodeksā, kā arī Eiropas mediatoru rīcības kodeksā.

Tā kā mediācija ir starpdisciplināra darbības joma, kas aptver gan psihologiju, gan jurisprudenci, gan sociologiju, gan citas jomas, arī mediatora darbā apzinātībai (mindfulness) ir būtiska nozīme. Mediācijas procesa laikā ne vien puses ir konflikta situācijā, arī mediators neizbēgami kḷūst par konflikta daļu. Viṇam jāsastopas ar dažāda veida grūtībām - gan emocionālām, gan cita rakstura. Tas, kas notiek mediācijas procesā, vienmēr izraisa jūtas un emocijas kā pusēm, tā arī mediatoram. Veiksmīgs mediators spēj apzināties un pārvarēt šìs grūtības, palīdzot pusēm mediācijā sasniegt labāko iespējamo risinājumu.

\section{Mediācijas pušu uzticēšanās iegūšana}

Pieredzējuši mediatori ir vienisprātis - mediācijas pušu uzticēšanās ir nozīmīgs veiksmīgas mediācijas priekšnoteikums. Pušu uzticēšanās mediatoram atvieglo sarunas uzsākšanu, palīdz atklāt pušu pozīcijas un vajadzības, bieži sniedz piekḷuvi svarīgai, līdz mediācijai nevienam neizpaustai informācijai, kas nereti ir patiesais domstarpību avots.

Lai mediācijas puse piekristu iesaistīties mediācijas procesā, tai ir jāsasniedz noteikts uzticēšanās slieksnis. Tomēr šī uzticēšanās neaprobežojas ar uzticēšanos mediatoram vien. To veido četri elementi:

1) uzticēšanās mediatoram;

2) uzticēšanās mediācijas procesam;

3) paļaušanās uz paša spējām veikt pārrunas;

4) uzticēšanās otrai pusei. ${ }^{1}$

Mediatoram jāiegūst pušu uzticēšanās jau mediācijas sākuma stadijā. Tas nav vienkāršs uzdevums, n,emot vērā, ka ne visi zina, ko dara mediators un kā norit mediācijas process. Jāspēj pārvarēt skepsi pret mediācijas procesu un atklāti un godīgi runāt par iemesliem, kas liek apšaubīt piemērotību mediācijai vai gatavību to uzsākt. ${ }^{2}$

Ir l̦oti daudz dažādu aspektu, kas ietekmē uzticēšanās veidošanu starp pusēm un mediatoru. Katrā mediācijas procesā tie ir individuāli un unikāli. Uzticēšanās var balstīties gan uz ārējām, gan iekšējām mediatora kvalitātēm, ko katra puse izvērtē un vai nu saprot un pien,em tās, vai pretēji - neuztver un tāpēc pieņemt nevar. Liela nozìme ir katras puses un arī mediatora audzināšanai, kultūrai, izpratnei, stereotipiem, vērtību sistēmai un pieredzei. Šḳietamas nianses mediatora uzvedībā vai tēlā var vai nu radìt, vai pilnīgi sagraut uzticēšanos. Tā, piemēram, mediatora labvēlīga attieksme un

1 Davis M. A., Gadlin H. Mediators Gain Trust the Old-Fashioned Way - We Earn It! Negotiation Journal, January, Plenum Publishing Corporation, 1988, p. 55.

2 Ibid., p. 58. 
empātija. Lai puses justos mierīgi, tām ir jāgūst pārliecība, ka mediatoram par viṇiem ir pozitīvs iespaids ${ }^{3}$ un kaut kādā veidā pusēm jāsajūt, ka mediatoram rūp viṇu bažas. ${ }^{4}$

Liela nozīme ir arī mediatora profesionālajai reputācijai. ${ }^{5}$ Šajā ziñā pušu uzticēšanos var vairot iepriekš veiksmīgi veiktie mediācijas procesi. Diemžēl, ņemot vērā faktu, ka mediācija ir konfidenciāla un bieži mediācijas dalībnieki labprātāk noklusēe ka domstarpības ir bijušas un atrisinātas ar mediācijas palīdzību, mediatori nav tik zināmi. Dažiem mediācijas dalïbniekiem uzticēšanos mediatoram vairo un kā reputācijas garants kalpo, ja mediatoru iesaka tiesa un mediators ir sertificēts vai ir kādas pazīstamas organizācijas vai institūcijas dalībnieks.

Svarīgs ir arī veids, kā mediators vada mediācijas procesu. ${ }^{6}$ Ja pusēm rodas pārliecỉba, ka mediators tiek galā ar mediācijas procesa vadību, tas vairo pušu paļaušanos un uzticēšanos. Ja puses procesa laikā piedzīvo un tām ir iespēja pārliecināties, ka mediators stingri turas pie mediācijas sākumā nospraustiem principiem, piemēram, neitralitāti pret pusēm, konfidencialitāti, cieņpilnu attieksmi pret pusēm un viņu situāciju, mieru, pušu uzticēšanās aug gan pret mediatoru, gan mediācijas procesu, gan viņu pašu spēju savstarpēji vienoties.

Nozīmīga ir mediācijas procesa būtības izpratne. Jo īpaši, ja tās aspekti nav viennozīmīgi. Piemēram, kā gadỉjumā ar konfidencialitāti. Tā nav apšaubāma un ir pilnīgi nepieciešama pušu uzticēšanās vairošanai, tomēr mulsumu var radīt likumdošanā paredzētie izṇēmumi. Ir svarīgi ne tikai izrunāt šos jautājumus pašā mediācijas procesa sākumā, bet arī pārliecināties, ka puses mediācijas procesa būtību ir pilnīgi izpratušas.

Savukārt dạ̧a zinātnieku apgalvo, ka uzticēšanās veidojas pakāpeniski, jo svarīga nozīme ir pierašanai. Viṇu novērojumi liecina, ka komforta un uzticēšanās līmenis vairojas, vienkārši pavadot vairāk laika kopāa ar mediatoru.?

Īpaši uzticēšanās radī̌sanā starp pusēm un mediatoru, tiek izcelta mediatora neitralitātes un objektivitātes nozīme.

\section{Mediatora neitralitāte}

Mediatora neitralitātes nepieciešamība uzsvērta visās definīcijās par mediāciju un mediatoru, kā arī skaidri atrunāta visos ar mediāciju saistītajos likumos un ētikas normās. Bet ko nozīmē neitralitāte mediācijā? Vai praktiski ir iespēja palikt pilnīgi neitrālam pret iesaistītajām pusēm, vienlaikus esot godīgam pret abām?

Nozares literatūra nesniedz skaidru un nepārprotamu neitralitātes definīciju, ši jēdziena pētnieki piedāvā atšķirīgus jēdziena nozīmes skaidrojumus. Tiek minēti

3 Pruitt D. G., Lewis S. A. Achieving integrative agreements. In: Bazeman M. H., Lewicki R. J. (eds.). Negotiations in Organizations, Sage Publications, 1983, p. 47.

4 Augsburger D. W. Conflict mediation across culture:Pathways and Patterns. Westminter / John Knox Press, 1992, p. 191.

5 Poitras J. What Makes Parties Trust Mediators? Negotiation Journal, July, 2009, p. 308.

6 Ibid., p. 309.

7 Lewicki R. J., Wiethoff C. Trust, trust development, and trust repair. The Handbook of Conflict Resolution: Theory and practice. 2000. Jossey-Bass, p. 99. 
trīs galvenie principi attiecībā uz neitralitāti. Pirmkārt, neitralitāte "bezpartejiskuma" nozīmē, paredzot objektivitāti pret pusēm. Jāteic, visai paredzami - arī objektivitātes jēdziens nav nepārprotams, un to mēdz izprast dažādi. Saskaņā ar šauro definīciju, objektivitāte ir brīvība no interešu konflikta. Pēc plašākās definīcijas - objektivitāte tiek pielīdzināta mediatora personisko vērtību, priekšnosacījumu un vēlmju radītu aizspriedumu neesamībai. ${ }^{8}$

Otrkārt, neitralitāte pauž vienlīdzīgu attieksmi pret pusēm. ${ }^{9}$ Tas nozīmē, ka, no mediatora viedokḷa, pusēm ir pilnīgi vienādas tiesības, pienākumi, piekḷuve resursiem, informācijai, mediatora laikam. Vērā netiek n,emti nedz reliğiskie, nedz vecuma vai dzimuma, vai jebkuri citi aizspriedumi, kas pastāv katrā sabiedrībā.

Treškārt, paredz mediatora neitralitāti par saturu un mediācijas rezultātu, bet nenoliedz atbildỉbu par procesa vadību. ${ }^{10}$ Tātad mediatoram jāprot un jāspēj nodot atbildību par domstarpību risināšanas procesu un rezultātu pusēm. Tas izklausās vieglāk, nekā ir praksē. Nedrīkst aizmirst, ka arī mediators ir cilvēks ar saviem priekšstatiem par taisnīgumu. No viņa netiek prasīts atteikties no saviem priekšstatiem, lai kādi tie būtu. No mediatora sagaida, ka viņš nepiel̦aus, ka viņa priekšstati ietekmēs mediācijas procesu. Tādēḷ mediatoram ir svarīgi izzināt pašam sevi, t. i., noskaidrot savus priekšstatus par taisnīgumu. ${ }^{11}$ Mediators, kas labi pazīst sevi, ir saskaṇā ar sevi, daudz labāk spēj saprast un palikt neitrāls pret mediācijas pusēm. Lai vairotu mediatora saskaṇu ar sevi, mediatori bieži veic dažādus paškontroles vingrinājumus, apmeklē supervīzijas un terapijas, nemitīgi veic pašanalīzi un trenē apzinātību.

\section{Apzinātības loma mediatora darbā}

Šajā rakstā autores piedāvā tikai nelielu ieskatu rietumnieciskai pieejai apzinātības jēdzienam un apzinātības prakses pamatojumam un iespējām mediatoriem. Mediācijā ir svarīgi, kā mediatori jūtas un kāda ir pasaule ap viņiem un viņos. No tā ir atkarīgs, kā mediators vadīs mediācijas procesu un kādu iespaidu tas atstās uz mediācijas pusēm. Mediatora prasme vadìt procesu un izmantot dažādas tehnikas ir svarīga, bet būtiskākais ir paša mediatora treniņš un prasmes, personas intelektuālās un garīgās kvalitātes. Mediācijas vadīšanas instruments ir ne tikai speciālista profesionālā kompetence, bet arī viņa personība un tās īpašības. Zināšanas var iegūt no grāmatām vai lekcijās, un specifiskās prasmes var apgūt darbā, tomēr to vērtỉba būs maza, ja nepilnveidosies pati personība. ${ }^{12}$ Šì spēja rodas ne tik daudz caur vārdiem, darbībām vai izturēšanos, cik caur mediatora personīgajām kvalitātēm, mediatora tēla veidošanu, gaisotnes radīšanu, mieru un iekšējo klusuma sajūtu. Tas var veicināt labu lēmumu pieṇemšanu mediācijas

8 Bush R. Efficiency and Protection, or Empowerment and Recognition. The Mediator's Role in Ethical Standards in Mediation. Florida Law Review, Vol. 41, No. 2, 1989, p. 86.

9 Boulle L. Mediation: Principles, Process, Practice, $2^{\text {nd }}$ ed., Butterworths, 2005, p. 32.

10 Douglas S. Mediator Neutrality: a Model for Understanding Practice, 2009, p. 40.

11 Rīle E. Konflikti un taisnīgums. Grām.: Leiendekers A. Konfliktu vadība. Konfliktu vadỉbas prasmes un kompetences mūsdienīgiem vadītājiem. Rīga: J.L.V., 2016, 77.lpp.

12 Sudraba V., Mārtinsone K. Grupu psiholog̣iskā konsultēšana un psihoterapija. Rīga: RSU, 2018, 67. lpp. 
procesā. ${ }^{13}$ Tāpat arī mediatora spēja dot cilvēkam telpu, kurā var justies droši, kurā viņš netiek uztverts ar aizspriedumiem vai pieņēmumiem. Bezaizspriedumu attieksme l̦auj ne tikai pien,emt puses un saprast, kā tās uztver sevi un savu vērtību sistēmu, bet arī saprast pušu vērtības un uzskatus no vin,u skatu punkta. Mediatoram ir l̦oti svarīgi, ka puses klausās un tiek uzklausītas, ka tās saṇem pilnīgu uzmanību un sapratni.

Spēja izzināt paša apziņu un sajust citu cilvēku iekšējo pasauli ir unikāls cilvēka talants. Sevis apzināšanās un empātija, apvienota ar sevis pārvaldīšanu un sociālajām prasmēm, ir nepieciešamas pilnvērtīgai dzìvei. No šīm četrām dzīves prasmēm sevis apzināšanās ir pārējo pamatā. Ja nespējam novērot savas emocijas, nevaram tās pārvaldīt un mācīties no tām. Ja esam atslēgti paši no savas pieredzes, grūti pieslēgties un uztvert arī citu emocijas. Veiksmīga savstarpēja sadarbība jeb saprašanās ir atkarīga no smalkas sevis apzināšanās, pārvaldīšanas un empātijas līdzsvara. ${ }^{14}$ Mediatora darbā un mediācijas procesā apzinātībai ir nozīmīga loma, jo spēja koncentrēt uzmanību jeb prāta koncentrēšana var palīdzēt mediatora neitralitātes un izpratnes veicināšanā. Apzinātība nozīmē veidot jaunas kategorijas, pieņemt jaunu informāciju, pien,emt vairāk nekā vienu nostāju. N̦emot vērā, ka emocijas ir visu konfliktu pamatā, neatkarīgi no tā, vai tas ir komercstrīds vai ǵimenes strīds, mediatora pienākums ir veidot tādu vidi, kurā neapzinātība var pārvērsties par apzinātību. Metodes, kuras mediatori izmanto mediācijas procesā, ir domātas, lai klientus vadītu uz apzinātību, proti: jautājumu uzdošana, pārfrāzēšana, aktīvās klausīšanās metožu izmantošana, teiktā apkopošana, pārtraukumi un individuālās sesijas. Apzinātības jēdziena nozīmīgumu pierāda fakts, ka pēdējos desmit gados apzinātības jēdzienu plaši izmanto psihologijas pētnieki un praktiḳi dažādās psiholoǵijas jomās, un daudzi pētījumi ir apstiprinājuši apzinātības jēgu un nozìmi. ${ }^{15}$ Apzinātība jeb iekšējā redze ir spēja ielūkoties sevī, kas sniedz iespēju atbrīvoties no tiem apziṇas veidiem un stāvokḷiem, kuri traucē pilnvērtīgi dzīvot. ${ }^{16}$ Gan psihoterapijas klasiķi (Zigmunds Freids, Karls Rodžers, Virdžīnija Satīra), gan pētījumi neirozinātnē rāda, ka viens no svarīgākajiem konsultanta darba instrumentiem ir pats konsultants, mediācijas gadījumā - pats mediators. Tādēḷ katram, kurš uzsācis ceḷu palīdzošās profesijas laukā, ir svarīgi izpētīt un izvērtēt savus motīvus, ietekmi un intereses. ${ }^{17}$

Apzinātība ir apzināšanās, kas atklājas caur uzmanības pievēršanu tagadnes brīdim ar nevērtējošu attieksmi uz lietām, kādas tās ir. Apzināšanās nozīmē pievērst uzmanību lietām, kādas tās patiesībā ir katrā momentā, lai kādas tās arī būtu, nevis kādas mēs gribētu, lai tās ir. Apzinātība tiek raksturota kā atvērts, uztverošs un pieņemošs prāta stāvoklis attiecībā pret šì brǐža pieredzi. Apzinātība ir nevērtējoša attieksme pret pieredzi, kas atklājas no mirkḷa uz mirkli. ${ }^{18}$ Apzinātības praksē tiek kultivētas tādas

13 Gereiša Z., Kirstuka L., Kḷave E. Mediācija. Jēdzieni. Testi. Lomu spēles. Mācību grāmata. Rīga: Tiesu namu aǵentūra, 2018, 79.-81. lpp.

14 Sīgels D. Apzinātība. Kā ieraudzīt sevi no malas un mainīt dzìvi. Rīga: Jumava, 2016, 51. lpp.

15 Kabat-Zinn J. Full Catastrophe living. Using the Wisdom of your Body and Mind to Face Stress, Pain, and Illness. New York: Bantam Books, 2013, p. 8.

16 Sigels D., 52. lpp.

17 Bite I., Mārtinsone K., Sudraba V., Ratniece G., Majore-Dūšele I., Berga G. u. c. Konsultēšanas un psihoterapijas teorija un prakse. Rīga: Zvaigzne ABC, 2016, 52. lpp.

18 Kabat-Zinn J., p. 230. 
īpašības kā nekritizēšana, pacietība, uzticēšanas gan sev, gan apkārtējiem, nepieķeršanās, atvērtība notiekošajam, interese, pateicība, empātija, piedošana, nekaitēšana sev un citiem, prieks un līdzsvarotība. Apzinātībā tiek pievērsta uzmanība nevērtējošai, konstatējošai attieksmei pret sajūtām, domām par to, kas šobrīd notiek ķermenī, prātā un ārpasaulē, tādējādi veidojot reālu, patiesu, nevērtējošu skatijumu uz konkrēto brīdi. Mediatora personības iezīmes, kas raksturīgas kvalitativām sadarbības attiecībām, ir godīgums, patiesums, spēja uzklausìt, empātija, izpratne, pieņemšana, pārliecība par sevi un spēja sadarboties. ${ }^{19}$ Tāpēc tādi apzinātības treniṇi kā pamanīšana - iekšèjās un ārējās pieredzes ievērošana un uzmanības pievēršana domām, skaṇām, sajūtām, jūtām utt.; aprakstīšana - spēja pamanīto pieredzi aprakstīt vārdos; apzināta rīcība - koncentrēšanās, uzmanības vēršana uz konkrēto brīdi, kam seko apzināta, nevis automātiska darbība; nevērtēšana - spēja pien,emt gan labas, gan sliktas domas ar nekritizējošu, pien,emošu attieksmi - mediatora praksē ir l̦oti vērtīgi un vajadzīgi. ${ }^{20}$ Tas nozìmē, ka, atpazīstot vecos domāšanas, reagéěšnas model̦us, trenējot apzinātību, mainās neironu cel̦i, veidojas jauni savienojumi, kas dod iespēju pārveidot iekšējo pieredzi, mainīt domāšanas un darbības virzienus, tādējādi bieži vien uzlabojot dzīves kvalitāti.

Apzinātība konceptuāli ir arī kā psihologiska indivīda iezīme, kas nozīmē būt apzinātam ikdienas dzīvē. Apzinātības praktizēšanas tehnikas ir dažādas, tomēr tās vieno trīs kopīgas iezīmes, kas vienlaikus raksturo apzinātību kā stāvokli. ${ }^{21}$ Pirmā iezīme ir apzināšanās, kas ietver apstāšanos, nevērtēšanu un atgriešanos. Apstāšanās nozīmē padarīt lēnākas ikdienas darbības, pārslēgties no automātiska režīma uz patiesu uzmanības pievēršanu tam, ko darām, kas notiek konkrētajā brīdī. Novērošana attiecas uz uzmanības koncentrēšanu, nevērtējošu vērošanu no malas, vērojot, kas notiek k̦ermenī, elpā un sajūtās. Atgriešanās nozìmē, ka brīdī, kad uzmanības fokuss pazūd, notiek maiga, nekritizējoša tās virzīšana atpakal pie sajūtām ķermenī un pie elpošanas. Domu saturam vai emociju analīzei netiek pievērsta uzmanība. Otrā iezīme ir klātbūtne jeb tagadnes brīdis. Apzinātības praksēs uzmanība tiek pievērsta tieši ķermeniskajām sajūtām, elpošanai, jo atšķirībā no prāta ķermenis vienmēr ir šeit un tagad. K,ermeña sajūtas iedod tūlìtēju atgriezenisko saikni par to, kas notiek mūsu emocionālajā un mentālajā stāvoklī. Var teikt, ka apzinātības mērḳis ir palīdzēt cilvēkiem tagadnes brīdī būt vienotiem ar to darbību, kas tiek veikta. ${ }^{22}$ Trešã iezīme ir pien,emšana, kas ir spēja skatīities uz lietām tādām, kādas tās ir, bez kritikas vai specifiskām vēlmēm, bet gan ar ieinteresētību un laipnību. Tas nenozīmē pasìvu attieksmi, tā ir prasme reāli uztvert norises, tās pien,emt un atbilstoši reaǵèt. ${ }^{23}$

Apzinātība ietekmē gan kognitīvos, gan emocionālos, gan arī neirofiziologiskos indivīda aspektus. Tātad sava prāta un ķermeṇa apzināšanās var palīdzēt veikt radikālas

19 ГАәААинг С. Психологическое консультирование. 4-е изА. Серия "Мастера психологии". Санктпетербург: Питер, 2002, с. 47-48.

20 Shapiro S. L., Astin J. A., Bishop S. R., Cordova M. Mindfulness Based Stress Reduction for Health Care Professionals: Results from Randomized Trial. International Journal of Stress Management. V. 12(2), 2005, p. 166.

${ }^{21}$ Williams M., Teasdale J., Segal Z., Kabat-Zinn J. The Mindful Way through Depresion. New York, London: The Guilford Press, 2007, p. 47.

22 Bite I., Mārtinsone K., Sudraba V., Ratniece G., Majore-Dūšele I., Berga G. u. c., 374. lpp.

23 Williams M., Teasdale J., Segal Z., Kabat-Zinn J. The Mindful Way through Depresion, p. 180. 
pārmaiṇas indivīda attiecībās ar negatīvām domām un jūtām. Pievēršot uzmanību kaut vai vienam no šiem aspektiem - emocijām, domām, fiziskām sajūtām, indivīds kḷūst apzināts, ir klātesošs un galvenais - nevērtējošs. Ikvienam mediatoram savas prakses laikā būtu vēlams un ieteicams padomāt par šīm palīdzīgajām apzinātỉbas praksēm un iespējamām izmaiṇām, ko tās rada, un ieviest kā savas psihiskās veselības atbalstošu instrumentu.

\section{Kopsavilkums}

1. Pušu uzticēšanās mediatoram ir veiksmīgas mediācijas priekšnoteikums. Tās iegūšana ir smags un atbildīgs mediatora uzdevums un mediatora profesionālo iemaņu un personīgo rakstura īpašỉbu mijiedarbỉbas rezultāts.

2. Mediatora neitralitāte vairo uzticēšanos mediatoram un ir viena no mediatora profesionalitātes rādītājiem. Mediatora neitralitāte nenoliedz mediatora personīgo uzskatu esamību, tomēr tie nedrīkst ietekmēt mediācijas procesu. Neitralitāte paredz vienlìdzīgu, pieņemošu, atbalstošu un no stereotipiem brivvu attieksmi pret abām pusēm.

3. Apzinātība konceptuāli ir arī kā psihologiska indivīda iezīme, kas nozīmē būt apzinātam ikdienas dzīvē. Apzinātības mērḳis ir palīdzēt cilvēkiem tagadnes brīdī būt vienotiem ar darbïbu, kas tiek veikta.

4. Savas būtības, esības apzināšanās var palīdzēt veikt radikālas pārmaiņas indivīda attiecībās ar negatīvām domām un jūtām. Emocijas, domas, fiziskās sajūtas, indivīda apzinātība, klātbūtne (klātesamība) un galvenais - nevērtēšana ir aspekti, kuriem pievēršot uzmanību mediators var sasniegt izcilību.

\section{BIBLIOGRĀFIJA}

1. Augsburger D. W. Conflict mediation across culture: Pathways and Patterns. Westminter: John Knox Press, 1992.

2. Bite I., Mārtinsone K., Sudraba V., Ratniece G., Majore-Dūšele I., Berga G. u. c. Konsultēšanas un psihoterapijas teorija un prakse. Rìga: Zvaigzne ABC, 2016.

3. Boulle L. Mediation: Principles, Process, Practice. $2^{\text {nd }}$ ed. Chatswood, N.S.W.: Butterworths, 2005.

4. Bush R. A. B. Efficiency and Protection, or Empowerment and Recognition. The Mediator's Role in Ethical Standards in Mediation. Florida Law Review, Vol. 41, No. 2, 1989, pp. 252-286.

5. Davis M. A., Gadlin H. Mediators Gain Trust the Old - Fashioned Way - We Earn It! Negotiation Journal. Plenum Publishing Corporation, January, 1988.

6. Douglas S. Mediator Neutrality: A Model for Understanding Practice. PhD Thesis, 2009.

7. Kabat-Zinn J. Full Catastrophe living. Using the Wisdom of your Body and Mind to Face Stress, Pain, and Illness. New York: Bantam Books, 2013.

8. Gereiša Z., Kirstuka L., Kḷave E. Mediācija. Jēdzieni. Testi. Lomu spēles. Mācību grāmata. Rīga: Tiesu namu aǵentūra, 2018. 
9. Lewicki R. J., Wiethoff C. Trust, trust development, and trust repair. The Handbook of Conflict Resolution: Theory and Practice. Jossey-Bass, 2000.

10. Poitras J. What Makes Parties Trust Mediators? Negotiation Journal. July, 2009. Vol. 25 (3), pp. 307-325.

11. Pruitt D. G., Lewis S. A. Achieving integrative agreements In: Bazerman M. H., Lewicki R. J. Negotiations in Organizations. Sage Publications, 1983.

12. Rīle E. Konflikti un taisnīgums. Grām.: Leiendekers A. Konfliktu vadỉba. Konfliktu vadỉbas prasmes un kompetences mūsdienīgiem vadītājiem. Rīga: J.L.V., 2016, 73.-78. lpp.

13. Shapiro S. L., Astin J. A., Bishop S. R., Cordova M. Mindfulness Based Stress Reduction for Health Care Professionals: Results from Randomized Trial. International Journal of Stress Management. Vol. 12 (2), 2005, pp. 164-176.

14. Sīgels D. Apzinātỉba. Kā ieraudzìt sevi no malas un mainīt dzìvi. Rīga: Jumava, 2016.

15. Sudraba V., Mārtinsone K. Grupu psihologiskā konsultēšana un psihoterapija. Rīga: RSU, 2018.

16. Williams M., Teasdale J., Segal Z., Kabat-Zinn J. The Mindful Way through Depresion. New York, London: The Guilford Press, 2007. 